\title{
Feeding of dried sweet orange (Citrus sinensis) peel on humoral immune response of broiler chickens
}

\author{
Z. Pourhossein ${ }^{1} \cdot$ A. A. A. Qotbi ${ }^{1}$ A. Seidavi ${ }^{2} \cdot$ V. Laudadio ${ }^{3} \cdot$ D. Mazzei $^{3} \cdot$ V. Tufarelli $^{3}$ (1)
}

Received: 24 January 2019 / Accepted: 25 May 2019 / Published online: 5 June 2019

(c) The Author(s) 2019

\begin{abstract}
Purpose An experiment was conducted to evaluate the effect of dried sweet orange (Citrus sinensis) peel (DCSP) on humoral immune response of broiler chickens.

Methods Four hundred 1-day-old Ross 308 broilers were distributed according to a completely randomized design into five treatments with four replicates of 20 chicks each. The following five dietary treatments were applied: control group with $0 \%$ DCSP; diet containing 1.5\% DCSP from 1 to 21 days of age (starter phase) and from 1 to 42 days of age, respectively; and diet containing 3\% DCSP from 1 to 21 days of age (starter phase) and from 1 to 42 days of age, respectively.

Results The DCSP treatments influenced positively total anti-SRBC and IgG titers on days 28 and 42, whereas no differences were found for IgM titer. The anti-NDV titers were not affected by diets; conversely, the anti-AIV titers were different among treatments. The anti-IBD titers were different on days 14 and 42 among diets, whereas anti-IBV titers were not influenced by treatments. Average white blood cell, heterophil, lymphocyte, and monocyte counts, as well as heterophil/lymphocyte $(H / L)$ ratio, were different among treatments.

Conclusion The findings suggested that the dietary inclusion of dried Citrus sinensis promoted some effects on the immune humoral response of chickens; however, these effects were not completely effective to protect birds from the main diseases.
\end{abstract}

Keywords Nutrition $\cdot$ Citrus sinensis $\cdot$ Broiler $\cdot$ Immunity

\section{Introduction}

The significant level of consumer expectations and sensitivity relative high protein intake will increase the demand for poultry meat (Laudadio et al. 2012). The use of additives in poultry nutrition is considered a solution for better nutrient utilization. The use of growth promoters has resulted in a high rate of broiler production in recent years. At present, this trend has been changing due to the increase of production and concerns with environmental safety and public health (Gibson and Roberfroid 1995; Tufarelli et al. 2017).

\footnotetext{
V. Tufarelli

vincenzo.tufarelli@uniba.it

$1 \quad$ Young Researchers and Elites Club, Rasht Branch, Islamic Azad University, Rasht, Iran

2 Department of Animal Science, Rasht Branch, Islamic Azad University, Rasht, Iran

3 Department of DETO, Section of Veterinary Science and Animal Production, University of Study of Bari 'Aldo Moro', Valenzano, Bari, Italy
}

Infectious diseases of domestic animals and poultry cause huge economic losses worldwide. One solution to reduce the risk of infectious diseases is by using immune system stimulants (Dong et al. 2007; Qorbanpour et al. 2018). Herbal plants and their products such as essential oils, flavonoids, carotenoids, saponins, plant steroids, phenolic compounds, tannins, quinones, coumarin, lectin, polypeptides, insoluble non-starch polysaccharides, and oligosaccharides have been shown to enhance immune system and improve the poultry performance (Chen et al. 2003; Azizi et al. 2018).

The immunity of birds can be divided into humoral and cellular immunity. Humoral immunity is characterized by an adaptive function of the immune system, which produces antibodies in response to an antigen. Cellular immunity involves mechanisms by which cells infected with foreign agents such as viruses are destroyed directly by an effector (e.g., activated T cell) in contact with the target cell (Weinstock et al. 1989).

Lymphoid and non-lymphoid organs are two structural categories of immune system of birds. The bursa of Fabricius and the thymus, where $\mathrm{B}$ and $\mathrm{T}$ cells develop and 
differentiate, respectively, are considered primary lymphoid organs, whereas the spleen is regarded as a secondary lymphoid organ. Additionally, the lymphoid structures distributed along the gut also play an essential role in birds' immune protection. These immune structures represent an important immune barrier against many economically significant pathogens that replicate in the intestinal epithelium. Non-lymphoid components of the immune system include cells that provide a non-specific immune defense of the host (Qureshi et al. 1998; Marech et al. 2018). Klasing (1998) reports that factors related to bird genetics, frequency of their exposure to pathogens, and effectiveness of vaccination programs influence the incidence of infectious diseases in birds. However, diet characteristics, such as nutritional levels and types of feedstuffs, may affect the susceptibility of birds to infectious diseases.

The peel from Citrus sinensis is a significant source of pectin (a non-digestible carbohydrate), which stimulates the growth of probiotic bacteria in the colon, thereby preventing the growth of pathogenic bacteria. Sweet Citrus sinensis peel contains ethyl acetate extracts, which have been shown to inhibit the growth of Gram-positive bacteria (Staphylococcus aureus, Bacillus cereus, Listeria monocytogenes), yeasts, and molds (Chanthaphon et al. 2008; Pourhossein et al. 2015).

Therefore, considering all of the above, the aim of this study was to evaluate the effect of the dietary inclusion of different levels of dried Citrus sinensis peel on the humoral immune response of broilers.

\section{Materials and methods}

The experiment was conducted on a farm located in Some'esara, Guilan province, Iran. In total, 400 1-day-old Ross 308 broilers were housed in 20 cages $(2 \times 1 \times 1 \mathrm{~m})$ and distributed according to a completely randomized design into five treatments with four replicates of 20 birds each. The farm building was thoroughly cleaned and disinfected. House temperature was maintained by three gasoline rocket heaters and was controlled by three thermostats installed in different parts of the building. In order to provide moisture, water was sprayed on the floor in order to maintain 50-60\% moisture during the experimental period. Lighting was provided by windows and 26-watt fluorescent bulbs in three rows distant approximately $3 \mathrm{~m}$ from each other. The different treatments used to evaluate the humoral immune response of broilers were as follows (Table 1).

Control: Basal diet without any additive (Pourhossein et al. 2015).
Table 1 Ingredients and nutritional composition of diets

\begin{tabular}{lrr}
\hline Ingredients (\%) & Starter & Grower \\
\hline Corn grain & 54.32 & 58.69 \\
Soybean meal & 39.43 & 31.87 \\
Oyster shell & 0.90 & 0.79 \\
Vitamin and mineral premix $^{\mathrm{a}}$ & 0.50 & 0.50 \\
Salt & 0.37 & 0.37 \\
DL-methionine & 0.20 & 0.22 \\
L-Lysine & 0.07 & 0.05 \\
Corn oil & 2.16 & 5.83 \\
Dried Citrus sinensis & 2.05 & 1.68 \\
Nutritional composition & & \\
Metabolizable energy (kcal/kg) & 2.900 & 3.200 \\
Crude protein (\%) & 22.16 & 19.20 \\
Calcium (\%) & 1.00 & 0.80 \\
Available phosphorus (\%) & 0.50 & 0.42 \\
Lysine (\%) & 1.15 & 0.96 \\
Methionine (\%) & 0.50 & 0.48 \\
Methionine + cystine (\%) & 0.83 & 0.78 \\
Threonine (\%) & 0.79 & 0.71 \\
Dried Citrus sinensis (mEq/kg) & 236.00 & 202.00 \\
\hline
\end{tabular}

a Supplied per $\mathrm{kg}$ of diet: $12,000 \mathrm{IU}$ vitamin A, $10 \mathrm{mg}$ vitamin E, $2200 \mathrm{IU}$ vitamin D, $35 \mathrm{mg}$ niacin, $12 \mathrm{mg}$ D-pantothenic acid, $3.63 \mathrm{mg}$ riboflavin, $3.5 \mathrm{mg}$ pyridoxine, $2.4 \mathrm{mg}$ thiamine, $1.4 \mathrm{mg}$ folic acid, $0.15 \mathrm{mg}$ biotin, $0.03 \mathrm{mg}$ vitamin $\mathrm{B}, 60 \mathrm{mg}$ manganese, $40 \mathrm{mg}$ zinc, $1280 \mathrm{mg}$ iron, $8 \mathrm{mg}$ copper, $0.3 \mathrm{mg}$ iodine, and $0.2 \mathrm{mg}$ selenium

Basal diet $+1.5 \%$ dried Citrus sinensis peel for 1-21 days of age;

Basal diet $+1.5 \%$ dried Citrus sinensis peel for 1-42 days of age;

Basal diet $+3.0 \%$ dried Citrus sinensis peel for 1-21 days of age;

Basal diet $+3.0 \%$ dried Citrus sinensis peel for 1-42 days of age;

The feeds supplied during the experimental periods were formulated according to NRC (1994) and the chemical composition of dried sweet orange peel was analyzed using the AOAC (1990) method (Table 2).

Birds were vaccinated according to established research program against Infectious Bronchitis Virus (IBV), Avian Influenza virus (AIV), Newcastle disease virus (NDV)*** and Bursal infectious disease (IBD) by spray or drinking water. The antibody titers of the birds were analyzed on different days according to the type of vaccine. Serum antibodies were measured in one bird per replicate by ELISA (BioCheck) test. On days 21 and 35, a $0.5 \%$ of sheep red blood cells (SRBC) ( $0.1 \mathrm{~mL}$ per kg body weight) was injected into the wing vein of the birds. A week later (days 28 and 42) blood samples were taken, and serum was separated, followed by decomplementation at $56^{\circ} \mathrm{C}$ for $30 \mathrm{~min}$, using as 

of the orange peel
Table 2 Chemical composition

\begin{tabular}{lr}
\hline Composition & Amount $(\%)$ \\
\hline Dry matter & 88.00 \\
Protein & 5.46 \\
Calcium & 1.10 \\
Phosphorous & 0.05 \\
Ash & 7.00 \\
Carbohydrate & 63.54 \\
Ether extract & 2.00 \\
Fiber & 10.00 \\
\hline
\end{tabular}

diluent buffer PBS with $1 \%$ bovine serum albumin (BSA/ Fort Dodge $\left.{ }^{\circledR}-22 \%\right)$. Serum dilutions $(1: 2,1: 4,1: 8,1: 16$, $1: 32,1: 64,1: 128,1: 256,1: 512,1: 1024$ and $1: 2048)$ were prepared in 96-well microtiter plates followed by the addition of $25 \mu \mathrm{L}$ of $1 \%$ SRBC in each well, using the technique of simple hemagglutination, as described by Wegmann and Smithies (1965). After incubation for $45 \mathrm{~min}$, HI titers were reported based on $\log _{2}$. Serum dilutions $(1: 2,1: 4,1: 8,1: 16$, $1: 32,1: 64,1: 128,1: 256,1: 512,1: 1024$ and $1: 2048)$ were prepared in 96-well microtiter plates followed by the addition of $25 \mu \mathrm{L}$ of $1 \% \mathrm{SRBC}$ in each well. After incubation for $45 \mathrm{~min}$, HI titers were reported based on $\log _{2}$. Since IgM is sensitive to 2-Mercaptoethanol (2Me), IgM and IgG titers were obtained by fractionation of the total anti-SRBC titers. On day 42, blood samples were collected in tubes containing EDTA. Total leukocytes were counted in Neubaur hemocytometer. Blood smears were prepared and stained, and heterophils, monocytes, and lymphocytes were counted.

Data were submitted to analysis of variance using the General Linear Model (GLM) procedure of SAS statistical package (SAS Institute 2002) and in case of significant effect, means were compared by the test of Duncan at $5 \%$ probability level.

\section{Results and discussion}

The applied treatments influenced $(p<0.05)$ total anti-SRBC titers evaluated on days 28 and 42. On both days of data collection, average total anti-SRBC titer values were higher in the birds fed the diet with $1.5 \%$ of DCSP for $1-42$ days and in those fed the diet with $3 \%$ of DCSP for 1-21 days when compared with the other treatments. Average IgG titer values on days 28 and 42 were significantly different $(p<0.05)$ among treatments. No differences $(p>0.05)$ in average IgM titer values were found among treatments (Tables 3, 4 , respectively).

Antioxidants are abundant in fruits and vegetables and have the ability to neutralize free radicals and convert them into harmless molecules (Leonard et al. 2002). Therefore,
Table 3 Anti-SRBC (total), IgG, and IgM titers determined in 28-day-old broilers fed different dietary Citrus sinensis peel levels

\begin{tabular}{llll}
\hline Antibody titers at 28 days & & & \\
\hline Treatments & Anti-SRBC & $\operatorname{IgG}^{\mathrm{b}}$ & $\mathrm{IgM}^{\mathrm{c}}$ \\
\hline Control & $3.00 \mathrm{~b}$ & $1.50 \mathrm{c}$ & 1.50 \\
1.5\% DCSP 1-21 days & $3.12 \mathrm{~b}$ & $1.75 \mathrm{bc}$ & 1.37 \\
1.5\% DCSP 1-42 days & $4.75 \mathrm{a}$ & $2.87 \mathrm{a}$ & 1.88 \\
3.0\% DCSP 1-21 days & $4.12 \mathrm{a}$ & $2.25 \mathrm{ab}$ & 1.87 \\
$3.0 \%$ DCSP 1-42 days & $3.12 \mathrm{~b}$ & $1.50 \mathrm{c}$ & 1.62 \\
SEM & 0.32 & 0.24 & 0.23 \\
\hline
\end{tabular}

$a-b$ Means within the same column followed by different letters are significantly different $(P<0.05)$ (Duncan's test)

DCSP dried Citrus sinensis peel

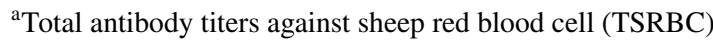

${ }^{\mathrm{b}}$ Immunoglobulin G (IgG)

${ }^{\mathrm{c}}$ Immunoglobulin M (IgM)

according to Byer et al. (2001), the increase of antioxidant levels decreases free radical reactions which may have beneficial effects on cell activity. Mona and Hanan (2007) showed in laying hens that Citrus sinensis peel can improve immune system activities due to their antioxidant properties.

According to Kayvan and Eshtiyaghi (1992), the living environment is full of pathogens, but the animal and human bodies have the ability to protect themselves with the help of the immune system. Citrus peel contains antioxidants (flavonoids), which are absorbed and metabolized by the body (Oluremi et al. 2010). The strong total anti-SRBC titer response of the chickens fed the diets with DCSP indicates that Citrus peel added to broiler diets enhances immunity. Yamamoto and Glick (1982), comparing the antibody-mediated immunity of broilers selected according to bursa of

Table 4 Anti-SRBC (total), IgG, and IgM titers determined in 42-day-old broilers fed different dietary Citrus sinensis peel levels

Antibody titers at 42 days

\begin{tabular}{llll}
\hline Treatments & Anti-SRBC $^{\mathrm{a}}$ & $\mathrm{IgG}^{\mathrm{b}}$ & $\mathrm{IgM}^{\mathrm{c}}$ \\
\hline Control & $4.50 \mathrm{~b}$ & $1.87 \mathrm{~b}$ & $2.63 \mathrm{a}$ \\
$1.5 \%$ DCSP 1-21 days & $5.50 \mathrm{~b}$ & $2.62 \mathrm{ab}$ & 2.88 \\
$1.5 \%$ DCSP 1-42 days & $7.00 \mathrm{a}$ & $3.62 \mathrm{a}$ & 3.38 \\
$3.0 \%$ DCSP 1-21 days & $5.87 \mathrm{ab}$ & $2.62 \mathrm{ab}$ & 3.25 \\
$3.0 \%$ DCSP 1-42 days & $4.75 \mathrm{~b}$ & $2.00 \mathrm{~b}$ & 2.75 \\
SEM & 0.46 & 0.36 & 0.27 \\
\hline
\end{tabular}

a-b Means within the same column followed by different letters are significantly different $(P<0.05)$

DCSP dried Citrus sinensis peel

${ }^{\text {a }}$ Total antibody against sheep red blood cell (TSRBC)

${ }^{\mathrm{b}}$ Immunoglobulin $\mathrm{G}$ ( $\mathrm{IgG}$ )

${ }^{\mathrm{c}}$ Immunoglobulin M (IgM) 
Fabricius size, reported, as shown in the present study, that increase percentage of SRBC injection concentration could achieve higher titers. Scott (1993), studying the diffusion of antibodies ac a sheep red blood cell membrane, observed that after birth, the sheep blood antibodies had parental origin and their values gradually decreased from 6 to 21 days, after which the body started to produce antibodies, thereby increasing their titers.

According to Leshchinsky and Klasing (2001) in experimental models, many parameters of the immune system, including the resistance to infections, specific antibody production, and numbers of antibody producing cells, are modified by diets supplemented or not with antioxidant substances. On both evaluation days (28 and 42), the lowest average $\operatorname{IgG}$ titer was obtained in the birds that received the control treatment and those fed the diet with 3\% DCSP for 1-42 days; however, the highest average value was observed in the birds fed the diet with $1.5 \%$ of DCSP for 1-42 days. According to Nysather et al. (1976), IgG protects the chicken by activating the complement system and by helping the antigen to be phagocytized by macrophages. Flavonoids act through antioxidant effects, direct removal of free-radicals, and effect on nit enzymatic systems. Citrus fruit flavonoids have synergistic effect on the immune system (Nijveldt and Boelens 2001).

The anti-NDV titers were not affected $(p>0.05)$ by the treatments (Table 5).

On the other hand, average anti-AIV titers were significantly different $(p<0.05)$ among treatments on days 14 and 28 (Table 6), with the control treatment promoting higher or statistical equal average titers when compared with the other treatments. The results indicated that citrus peel does not enhance the immune response of broilers against all pathogens and its action is selective in nature.

Results reported by Chen et al. (2003), who studied the effects of two Chinese herbal polysaccharides [achyranthan $(\mathrm{ACH})$, a low-molecular-weight polysaccharide, and astragalan, a high-molecular-weight polysaccaride] on the immunity and growth performance of young broilers, showed that

Table 5 Anti-newcastle disease virus (NDV) titers $\left(\log _{2}\right)$ of broilers fed different dietary Citrus sinensis peel levels as determined on 7, $14,28,35$, and 42 days of age

\begin{tabular}{|c|c|c|c|c|c|}
\hline \multicolumn{6}{|l|}{ Anti-NDV titers } \\
\hline Treatments & 7 & 14 & 28 & 35 & 42 \\
\hline Control & 5.00 & 5.75 & 4.75 & 5.00 & 5.50 \\
\hline $1.5 \%$ DCSP $1-21$ days & 4.50 & 5.50 & 4.50 & 5.00 & 6.00 \\
\hline $1.5 \%$ DCSP $1-42$ days & 4.25 & 4.75 & 4.00 & 4.75 & 4.75 \\
\hline $3.0 \%$ DCSP $1-21$ days & 4.50 & 5.50 & 4.50 & 5.00 & 6.25 \\
\hline $3.0 \%$ DCSP $1-42$ days & 5.00 & 5.00 & 4.25 & 5.00 & 5.25 \\
\hline SEM & 0.33 & 0.40 & 0.31 & 0.11 & 0.50 \\
\hline
\end{tabular}

Table 6 Anti-avian influenza virus (AIV) titers $\left(\log _{2}\right)$ of broilers fed different dietary Citrus sinensis peel levels as determined on 7, 14, 28,35 , and 42 days of age

\begin{tabular}{llllll}
\hline Anti-AIV titers & \multicolumn{7}{l}{} \\
\hline Treatments & 7 & 14 & 28 & 35 & 42 \\
\hline Control & 3.50 & $4.25 \mathrm{a}$ & $3.50 \mathrm{a}$ & 4.75 & 4.50 \\
1.5\% DCSP 1-21 days & 3.25 & $4.25 \mathrm{a}$ & $3.00 \mathrm{~b}$ & 4.75 & 5.00 \\
1.5\% DCSP 1-42 days & 4.00 & $3.25 \mathrm{~b}$ & $3.00 \mathrm{~b}$ & 3.75 & 3.75 \\
3.0\% DCSP 1-21 days & 4.25 & $4.00 \mathrm{ab}$ & $3.00 \mathrm{~b}$ & 4.50 & 4.75 \\
3.0\% DCSP 1-42 days & 4.00 & $4.00 \mathrm{ab}$ & $3.00 \mathrm{~b}$ & 4.50 & 4.50 \\
SEM & 0.33 & 0.27 & 0.13 & 0.37 & 0.40 \\
\hline
\end{tabular}

a-b Means within the same column followed by different letters are significantly different by the test of Duncan $(P<0.05)$

$\mathrm{T}$ and B lymphocyte counts increased with herbal polysaccharide consumption and antibody titers against a pathogenic ND virus. The supplementation of enzymes to wheat-based diets significantly increased the weight of the spleen, which is the main organ of the immune system (Guo et al. 2004). These enzymes increased antibody titers against ND, indicating enhanced humoral immune response. This enzyme increased lymphocyte and natural killer cell proliferation, showing that cell-mediated immunity was also affected, as also found in the present study. Average anti-IBD titers showed were significantly different $(p<0.05)$ among treatments on days 14 and 42 (Table 7). Average anti-IBV titers were not influenced $(p>0.05)$ by the treatments (Table 8$)$. The highest average anti-IBD titer was determined in the broilers fed the diet with $3 \%$ of DCSP from 1 to 21 days, and the lowest titer in those fed the diet with $1.5 \%$ of DCSP from 1 to 42 days. The results of the present study are similar to Puthpongsiriporn and Scheideler (2005), who showed that feeding laying hens with flaxseed in the diet did not affect the concentration of IBD and IBV vaccine titers.

Table 7 Anti-infectious bursal disease (IBD) titers $\left(\log _{2}\right)$ of broilers fed different dietary Citrus sinensis peel levels as determined on 14, 21 , and 42 days of age

\begin{tabular}{llll}
\hline Anti-IBD titers & & & \\
\hline Treatments & 14 & 21 & 42 \\
\hline Control & $6815 \mathrm{c}$ & 3678 & $2098 \mathrm{~b}$ \\
1.5\% DCSP 1-21 days & $8583 \mathrm{bc}$ & 4744 & $3847 \mathrm{~b}$ \\
1.5\% DCSP 1-42 days & $774 \mathrm{c}$ & 6177 & $6612 \mathrm{a}$ \\
$3.0 \%$ DCSP 1-21 days & $12595 \mathrm{a}$ & 4699 & $3320 \mathrm{~b}$ \\
$3.0 \%$ DCSP 1-42 days & $10943 \mathrm{ab}$ & 6204 & $4499 \mathrm{~b}$ \\
SEM & 805 & 848 & 1115 \\
\hline
\end{tabular}

$a-b$ Means within the same column followed by different letters are significantly different by the test of Duncan $(P<0.05)$ 
Table 8 Anti-infectious bronchitis virus (IBV) titers $\left(\log _{2}\right)$ of broilers fed different dietary Citrus sinensis peel levels as determined on 14, 21 , and 42 days of age

\begin{tabular}{llll}
\hline Anti-IBV titer & & & \\
\hline Treatments & 14 & 21 & 42 \\
\hline Control & 4166.5 & 2727.3 & 340.5 \\
1.5\% of DCSP 1-21 days & 3816.3 & 3765.5 & 1032.8 \\
1.5\% of DCSP 1-42 days & 3186.3 & 3750.5 & 1430.0 \\
3.0\% of DCSP 1-21 days & 5299.5 & 3374.5 & 746.3 \\
3.0\% of DCSP 1-42 days & 4542.0 & 4255.0 & 906.0 \\
SEM & 509 & 557 & 388 \\
\hline
\end{tabular}

Average white blood cell, heterophil, lymphocyte, and monocyte counts, as well as heterophil/lymphocyte ratio were different $(p<0.05)$ among treatments (Tables 9,10 , respectively).

Average spleen and bursa weights were not significantly different $(p>0.05)$ among treatments (Table 10). The results of the present study are consistent with those presented by Mona and Hanan (2007), who studied the effects of dried Egyptian clover and orange peels as natural feed additives on immune response of laying hens. Those authors found significantly different hematocrit and red blood cell and white blood cell counts among treatments ( 0.4 of dry clover; 0.2 of dry clover +0.2 of Citrus sinensis and 0.4 of dry clover +0.2 of Citrus sinensis). It may be due to the adequate amount of alpha-tocopherol in blood that simultaneously ingested the highest amounts of the vitamin C. The enhancement of the function of broilers fed orange peel in the present trial is in agreement with the results of Ding et al. (2004), who found that orange peel greatly improved the immune function. The effect of orange peel may be attributed to its antioxidant activity. Manthey (2004) showed that most of the antioxidant activity of orange peel was due to minor-occurring flavones. Orange peel extract components may counteract enzymatic lipid peroxidation processes (Malterud and Rydland 2000).

Vitamin C and polyphenols present in Citrus sinensis enhance the activity of antioxidant enzymes in red and white
Table 10 Heterophil/lymphocyte ratio and spleen and bursa weights of broilers fed different dietary Citrus sinensis peel levels

\begin{tabular}{llll}
\hline Treatments & $H / L$ & Spleen $(\mathrm{g})$ & Bursa $(\mathrm{g})$ \\
\hline Control & $88.25 \mathrm{a}$ & 2.89 & 1.15 \\
1.5\% DCSP 1-21 days & $71.24 \mathrm{ab}$ & 3.35 & 1.11 \\
1.5\% DCSP 1-42 days & $77.90 \mathrm{a}$ & 3.66 & 1.31 \\
3.0\% DCSP 1-21 days & $69.50 \mathrm{ab}$ & 2.90 & 1.62 \\
$3.0 \%$ DCSP 1-42 days & $54.41 \mathrm{~b}$ & 2.95 & 1.31 \\
SEM & 6.55 & 0.15 & 0.10 \\
\hline
\end{tabular}

a-b Means within the same column followed by different letters are significantly different by the test of Duncan $(P<0.05)$

$H / L$ heterophil to lymphocyte ratio

blood cells (Dragsted et al. 2001). According to Imboden et al. (1985), the polysaccharides found in Citrus sinensis significantly increase calcium concentration, which is an important regulator of lymphocyte activity and conduct lymphocyte signals, promoting the lymphocytes' proliferation. Vitamin $\mathrm{C}$ and vitamin $\mathrm{E}$ are important antioxidants that strengthen leukocyte membranes and, in appropriate amounts, increase heterophil phagocytosis activity (McFarland et al. 2005). Under heat stress situations, vitamin $\mathrm{C}$ may alleviate the stress effects by reducing the release of glucocorticoids. The addition of $1 \%$ vitamin $\mathrm{C}$ in the diet may reduce the immune function due to reduction of heat stress and increase of corticosterone. Differences in the beneficial effects of adding vitamin $\mathrm{C}$ to the diet can be attributed to vitamin $\mathrm{C}$ instability under storage conditions (Spinosa et al. 2002).

According to Mogenet and Youbicier-Simo (1998), acute heat stress affects the immune responses of lymphoid organs (bursa, thymus, spleen), increasing monocyte and heterophil counts, and heterophil/lymphocyte ratio ( $H: L$ ratio), and the ascorbic acid in the plasma stimulates the immune response and increases IgG and IgM titers in broiler chickens. Karthiyaini and Philiomina (2009) reported that the birds under stress-fed diets with $0.03 \%$ of vitamin $\mathrm{C}$ presented lower $H: L$ ratio than those not fed vitamin $\mathrm{C}$, indicating that this
Table 9 White blood cell (WBC) counts of broilers fed different dietary Citrus sinensis peel

\begin{tabular}{lllll}
\hline Treatments & WBC $\left(\times 10^{3}\right)$ & & & \\
\cline { 3 - 4 } & & Heterophil & Lymphocyte & Monocyte \\
\hline Control & $34.16 \mathrm{~b}$ & $45.25 \mathrm{a}$ & $51.50 \mathrm{~b}$ & $3.25 \mathrm{a}$ \\
$1.5 \%$ DCSP 1-21 days & $42.58 \mathrm{~b}$ & $40.75 \mathrm{ab}$ & $57.75 \mathrm{ab}$ & $1.50 \mathrm{~b}$ \\
$1.5 \%$ DCSP 1-42 days & $43.30 \mathrm{~b}$ & $42.50 \mathrm{a}$ & $55.00 \mathrm{~b}$ & $2.50 \mathrm{ab}$ \\
$3.0 \%$ DCSP 1-21 days & $30.69 \mathrm{a}$ & $39.25 \mathrm{ab}$ & $57.75 \mathrm{ab}$ & $3.00 \mathrm{a}$ \\
$3.0 \%$ DCSP 1-42 days & $44.38 \mathrm{~b}$ & 34.25 & $63.75 \mathrm{a}$ & $2.00 \mathrm{ab}$ \\
SEM & 4.4 & 2.2 & 2.3 & 0.46 \\
\hline
\end{tabular}

a-b Means within the same column followed by different letters are significantly different by the test of Duncan $(P<0.05)$ 
vitamin C reduces the effects of stress, suggesting that Citrus sinensis can be used in broiler diets for this purpose.

\section{Conclusions}

The inclusion of dried Citrus sinensis in broiler diet promoted positively some effects on the immune response; however, these effects were not completely effective to protect the birds against diseases such as infectious bursal disease, infectious bronchitis, Newcastle disease, or avian influenza.

Acknowledgements Financial support by Rasht Branch, Islamic Azad University, Grant number 4.5830 is gratefully acknowledged.

Open Access This article is distributed under the terms of the Creative Commons Attribution 4.0 International License (http://creativeco mmons.org/licenses/by/4.0/), which permits unrestricted use, distribution, and reproduction in any medium, provided you give appropriate credit to the original author(s) and the source, provide a link to the Creative Commons license, and indicate if changes were made.

\section{References}

AOAC (1990) Official methods of analysis, 15th edn. Association of Official Analytical Chemists, Washington, DC

Azizi M, Seidavi AR, Ragni M, Laudadio V, Tufarelli V (2018) Practical applications of agricultural wastes in poultry feeding in Mediterranean and Middle East regions. Part 1: citrus, grape, pomegranate and apple wastes. World Poult Sci J 74:489-498. https:// doi.org/10.1017/S0043933918000478

Byer T, Nestle M, McTiernan A, Doyle C, Currie WA, Gansler T, Thun M (2001) American cancer society guidelines on nutrition and physical activity for cancer prevention. Can J Clin Pharmacol 52:92-119

Chanthaphon S, Chanthachum S, Hongpattarakere T (2008) Antimicrobial activities of essential oils and crude extracts from tropical Citrus spp. against food-related microorganisms. Song J Sci Technol 30:125-131

Chen HL, Li DF, Chang BY, Gong LM, Dai JG, Yi GF (2003) Effects of Chinese herbal polysaccharides on the immunity and growth performance of young broilers. Poult Sci 82:364-370. https://doi. org/10.1093/ps/82.3.364

Ding G, Chen Z, Li W, Yang G, Xu CY (2004) Studies on effects of grass carp cell immune function by adding orange peels. Chin $\mathbf{J}$ Yun Agric Univ 19:727-730

Dong XF, Gao WW, Tong JM, Lia HQ, Sa RN, Zhang Q (2007) Effect of polysavone (Alfa Extract) on abdominal fat deposition and immunity in broiler chickens. Poult Sci 86:1955-1959. https:// doi.org/10.1093/ps/86.9.1955

Dragsted LO, Young JF, Loft S, Sandstrom B, Nesaretnam K, Packer L (2001) Biomarkers of oxidative stress and of antioxidative defense: relationship to intervention with antioxidant-rich foods. In: Nesratnem K, Packer L (eds) Micronutrients and health: molecular biological mechanisms. Danish Food Administration, Søborg, Denmark, pp 272-278

Gibson GR, Roberfroid MB (1995) Dietary modulation of the human colonic microbiota: introducing the concept of prebiotics. J Nutr 125:1401-1412. https://doi.org/10.1093/jn/125.6.1401
Spinosa HS, Górniak, SL, Bernardi MM (2002) Farmacologia Aplicada à Medicina Veterinária, Ed. Guanabara Koogan, 3a Edição, Rio de Janeiro, Brazil

Guo FC, Williams BA, Kwakkel RP, Li HS, Li XP, Luo JY, Li WK, Verstegen MWA (2004) Effects of mushroom and herb polysaccharides, as alternatives for an antibiotic, on the cecal microbial ecosystem in broiler chickens. Poult Sci 83:175-178. https://doi. org/10.1093/ps/83.2.175

Imboden JB, Weiss A, Stobo JD (1985) The antigen receptor on a human $\mathrm{T}$ cell line initiates activation by increasing cytoplasmic free calcium. J Immunol 134:663-665

Karthiyaini K, Philiomina PT (2009) Effect of vitamin c supplementation on some biochemical profile stressed broiler. In: Proceedings of the national seminar of recent trends in animal welfare and sustainable livestock production, Thrissur, India

Kayvan A, Eshtiyaghi R (1992) Immunologhy Royte Principios. Jahad-E-Keshavarzi Ed. University Medical Science, Tehran, Iran

Klasing KC (1998) Nutritional modulation of resistance to infectious diseases. Poult Sci 77:1119-1125. https://doi.org/10.1093/ ps/77.8.1119

Laudadio V, Nahashon SN, Tufarelli V (2012) Growth performance and carcass characteristics of guinea fowl broilers fed micronized-dehulled pea (Pisum sativum L.) as a substitute for soybean meal. Poult Sci 91:2988-2996. https://doi.org/10.3382/ ps.2012-02473

Leonard SS, Cutler D, Ding M (2002) Antioxidant properties of fruit and vegetable juices: more to the story than ascorbic acid. Ann Clin Lab Sci 32:193-200

Leshchinsky TV, Klasing KC (2001) Relationship between the level of dietary vitamin $\mathrm{E}$ and the immune response of broiler chickens. Poult Sci 80:1590-1599. https://doi.org/10.1093/ps/80.11.1590

Malterud KE, Rydland KM (2000) Inhibitors of 15-lipoxygenase from orange peel. J Agric Food Chem 48:5576-5580. https://doi. org/10.1021/jf000613v

Manthey JA (2004) Fractionation of orange peel phenols in ultrafiltered molasses and mass balance studies of their antioxidant levels. J Agric Food Chem 15:7586-7592. https://doi.org/10.1021/jf049 $083 \mathrm{j}$

Marech I, Ammendola M, Leporini C, Patruno R, Luposella M, Zizzo N, Passantino G, Sacco R et al (2018) C-Kit receptor and tryptase expressing mast cells correlate with angiogenesis in breast cancer patients. Oncotarget 9:7918-7927

Mc-Farland K, Catalano JF, Thrope SR, Baynes JW (2005) Nonenzymatic glucosylation of serum proteins in diabetes mellitus. Diabetes 28:1011-1014. https://doi.org/10.2337/diab.28.11.1011

Mogenet LY, Youbicier-Simo BJ (1998) Determination of reliable biochemical parameters of heat stress and application to the evaluation of medications: example of erythromycin E. In: Proceedings of 10th European poultry conference, Jerusalem, Israel, pp $538-541$

Mona SR, Hanan A (2007) Effects of using dried egyptian clover and orange peels as natural feed additives on egg production egg quality and immune response of laying hens. Fay J Agric Res Dev 21:188-205

Nijveldt RJ, Boelens Nood EV (2001) Flavonoids: a review of probable mechanisms of action and potential applications. Am J Clin Nutr 74:418-425. https://doi.org/10.1093/ajen/74.4.418

NRC (1994) Nutrient requirements of poultry, 9th edn. National Academy Press, Washington, DC

Nysather JO, Katz AE, Lenth JL (1976) The immune system: its development and functions. Am J Nurs 76:1614-1618

Oluremi OIA, Ebe AI, Ngi J, Aku EO (2010) Effect of naturally fermented sweet orange (Citrus sinensis) peel meal on its maize replacement value in broiler diet on performance and carcass 
indices. In: Proc. of 35th Ann. Conf. Nig. Soc. for Anim. Prod. 14-17 March, University of Ibadan, Nigeria, pp 449-542

Pourhossein Z, Qotbi AAA, Seidavi A, Laudadio V, Centoducati G, Tufarelli V (2015) Effect of different levels of dietary sweet orange (Citrus sinensis) peel extract on humoral immune system responses in broiler chickens. Anim Sci J 86:105-110. https://doi. org/10.1111/asj.12250

Puthpongsiriporn U, Scheideler SE (2005) Effects of dietary ratio of linoleic to linolenic acid on performance, antibody production, and in vitro lymphocyte proliferation in two strains of leghorn pullet chicks. Poult Sci 84:846-857. https://doi.org/10.1093/ ps/84.6.846

Qorbanpour M, Fahi T, Javandel F, Nosrati M, Paz E, Seidavi A, Ragni M, Laudadio V, Tufarelli V (2018) Effect of dietary ginger (Zingiber officinale Roscoe) and multi-strain probiotic on growth and carcass traits, blood biochemistry, immune responses and intestinal microflora in broiler chickens. Animals 8:117. https://doi. org/10.3390/ani8070117

Qureshi MA, Hussain I, Heggen CL (1998) Dietary exposure of broiler breeders to aflatoxin results in immune function in progeny chicks. Poult Sci 77:1126-1129. https://doi.org/10.1093/ps/77.6.812

SAS Institute (2002) SAS proprietary software release 9.2. SAS Inst. Inc., Cary

Scott LA (1993) Diffusion across a sheep red blood cell membrane. Test Stud Lab Teach 14:115-140
Tufarelli V, Crovace AM, Rossi G, Laudadio V (2017) Effect of a dietary probiotic blend on performance, blood characteristics, meat quality and faecal microbial shedding in growing-finishing pigs. S Afr J Anim Sci 47:875-882. https://doi.org/10.4314/sajas .$v 47 i 6.15$

Wegmann TG, Smithies O (1965) A simple hemagglutination system requiring small amounts of red blood cells and antibodies. Transfusion 6:67-73. https://doi.org/10.1111/j.1537-2995.1966.tb046 96.x

Weinstock D, Schat KA, Calnet BW (1989) Cytotoxic T lymphocyte sin reticulo endotheliosis virus-infected chickens. Eur J Immunol 19:267-272. https://doi.org/10.1002/eji.1830190208

Yamamoto Y, Glick B (1982) A comparison of the immune response between two lines of chickens selected for differences in the weight of the bursa fabricius. Poult Sci 61:2129-2132. https:// doi.org/10.3382/ps.0612129

Publisher's Note Springer Nature remains neutral with regard to jurisdictional claims in published maps and institutional affiliations. 